\title{
The dimensions of national competitiveness: The empirical analysis based on The World Economic Forum's data ${ }^{1}$
}

\author{
Hanna G. Adamkiewicz $z^{2}$
}

\begin{abstract}
The aim of this research is to determine the minimum number of uncorrelated dimensions which can describe national competitiveness (NC). NC is thought of as the ability of a nation to provide a conducive environment for its firms to prosper. It is shown that the environment affects national productivity catalytically through the interactions with the production factors while itself remaining unchanged. Selected World Economic Forum's indicators are used for determining the components of the environment. The Principal Component Analysis has revealed three orthogonal dimensions of NC. Countries are represented by the points in the three-dimensional space. The weighted Euclidean distance from the origin to the $i$ th point is proposed as a novel measure of the $i$ th country's level of NC.
\end{abstract}

Keywords: national competitiveness, productivity, catalyst, principal components.

JEL codes: C38, F13, O47, O57.

\section{Introduction}

The aim of this study is to determine the minimal number of uncorrelated dimensions which describe quantitatively national competitiveness (NC). The search for such dimensions was made empirically using indices which have been the basis of the World Economic Forum's (WEF) Global Competitiveness Index (GCI) up to the year 2017. ${ }^{3}$ The Principal Component Analysis (PCA) is applied in disclosing the dimensions. The results of the PCA will be used for elaborating a novel measure of NC.

\footnotetext{
${ }^{1}$ Article received 17 July 2019, accepted 16 September 2019.

${ }^{2}$ Gdansk University of Technology, Department of Economic Sciences, ul. Narutowicza 11/12, 80-233 Gdańsk, Poland, had@zie.pg.gda.pl, ORCID: https://orcid.org/0000-0003-1860-303X.

${ }^{3}$ In 2018 WEF made radical methodological changes in calculating GCI. However the new methodology does not preclude the need for a search for uncorrelated dimensions of international competitiveness.
} 
The aim has been motivated by the need for a precise quantitative measure of NC which might be incorporated into the Adamkiewicz and Kot's (2015) economic model of production (the A-K model for short). The cited authors note that the majority of concepts of $\mathrm{NC}$ refer to the capability of countries to create the environment for the system of production (EP) which supports firms and industries to prosper. The authors maintain that the recent models of economic growth have generally ignored a possible impact of EP on growth. Adamkiewicz and Kot specify two classes of the determinants of productivity: the production factors (physical capital, human capital and labour) and the catalysts. The A-K model is the Mankiw, Romer and Weil's (1992) model which is complemented by EP as the catalyst of productivity. EP enhances national productivity through interactions with the production factors while itself $r e$ maining unchanged. Accounting for NC in economic models has not, to our knowledge, been undertaken.

Adamkiewicz and Kot (2015) observe that some of WEF's indicators describe the components of EP quite well. This observation implies two important consequences. First, NC, as the product of the business school, can receive a convincing interpretation within the framework of the economic models of production. It is worth adding that the lack of economic background has been the main strand of academic economist criticisms of NC. This issue will be discussed in the next Section. Second, the WEF's indices of NC may be of use as the empirical basis of the quantitative assessments of the impact of $\mathrm{NC}$ on productivity in the A-K model.

The above explanations enable the more specific formulation of the authors' motivation. Adamkiewicz and Kot (2015) estimated their model using 24 WEF indices which satisfied the axioms of the catalyst. ${ }^{4}$ The selected indices were the basis of the calculation of the indicators of the catalysts which interact with the production factors. However the procedure of preparing the empirical basis for estimating the A-K model has some drawbacks. The calculation of the indicators seems to be arbitrary to a great extent. Moreover there might be overlap in the information provided by different indicators since the WEF's indices are correlated. Determining the uncorrelated dimensions of NC seems to be a remedy for the drawbacks.

The rest of this paper is organized as follows. Section 1 presents the review of the literature about the concepts of $\mathrm{NC}$ whose economic content may be attributed to EP. The construction of GCI is briefly presented in Section 2. In Section 3 the WEF's indicators are appraised from the EP point of view. Here the input-side indicators are selected. Section 4 presents the basic concepts and tools of PCA. Section 5 shows the empirical results of PCA. In Section 6

${ }^{4}$ Adamkiewicz and Kot (2015) propose five axioms which should be satisfied by the catalysts of productivity. 
countries are ranked according to the proposed measure of NC and productivity. The last section concludes.

\section{Literature review}

The aim of this Section is to review the concepts of NC whose economic content may be attributed to EP. More specifically the components of EP can be thought of as the determinants of NC and hence the potential catalysts of productivity. Almost all known concepts of NC have referred to productivity, either directly or indirectly. However the recent economic models of productivity have a closed set of production factors. The catalytic interactions of the components of EP with the factors of production seem to be the only room that economic models have left to NC.

Figuring the EP content out of NC is not an easy task. The main problem is the multitude of different definitions of $\mathrm{NC}$ which have been offered by the business-school-oriented researchers (see i.e. Boltho, 1995; Aiginger, 2006; Siggel, 2006). Since the literature on this topic is huge only some of the most important proposals will be mentioned.

Michael Porter's Competitive advantage of nations (1990a) has stimulated discussion on the concept of NC. ${ }^{5}$ He holds that there is not an accepted definition of the term 'competitiveness' as applied to nations. While the notion of competitiveness of a company or an industry is clear the notion of NC is not. The author maintains that "seeking to explain 'competitiveness' at the national level (then) is to answer the wrong question. What we must understand instead are the determinants of productivity and the rate of productivity growth". Porter (1990a, p. 6) emphasises that "[We] must abandon the whole notion of a 'competitive nation' as a term having much meaning for economic prosperity. The only meaningful concept of competitiveness at the national level is national productivity". He argues that "(...) the principal economic goal of a nation is to produce a high and rising standard of living for its citizens. The ability to do so depends not on the amorphous notion of 'competitiveness' but on the productivity".

Porter's (1990a) diamond of national advantage may be thought of as EP. He argues that the four determinants of the diamond " (...) create a national environment in which companies are born and learn how to compete. The main and most important role of nations is to establish an environment that supports the activities of companies". Garelli (2012) notices that companies are responsible for creating economic value while nations establish an environment to encourage/discourage firms to achieve that economic value.

${ }^{5}$ The edition of this monograph in 1990 was preceded by Porter's paper (Porter, 1990b) which summarised the crucial points of the monograph. 
The Porter qualitative model of the diamond of national advantage has been generalized by other authors into: the double diamond (Rugman \& D'Cruz, 1993), the generalized double diamond model (Moon, Rugman, \& Verbeke, 1998), the nine-factor model (Cho \& Moon, 2000) and the dual double diamond (Cho, Moon, \& Kim, 2009). The extended diamond models concern the role of FDI, human resources and international factors that have applicability at national level (Liu, 2017). The Porter model and the former three models have also applicability at industry level.

Kohler (2006) also favours the productivity approach to NC. He relates productivity to comparative advantage in trade theory and to total factor productivity in modern growth theory. "A country's welfare is determined by its absolute level of productivity and not by some international competitiveness rankings. (...) In a trading world, productivity is magnified in terms of its welfare potential by international exchange." Kohler is concerned with the terms of trade as a second principle determinant of domestic welfare.

WEF defines NC as " (...) the set of institutions, policies, and factors that determine the level of productivity of a country" (Sala-i-Martín \& Schwab, 2017, p. 11). This definition actually specifies the determinants of productivity rather than the notion of NC. It is worth adding that the term factors, as it appears in this definition of $\mathrm{NC}$, seems to have a different meaning from the production factors in economic growth theories. Indeed none of the WEF's indicators can be attributed to the production factors. Also none of the production factors is used for calculating GCI. Thus the WEF's definition of NC specifies the components of EP in which goods and services are produced and distributed.

Some authors note that EP is a potential for enhancing welfare. Aiginger (2006) defines NC as the ability of a country or a location to create welfare. Grilo and Koopman (2006) argue that standards of living are a meaningful measure of competitiveness and that improving competitiveness could be equated with enhancing welfare. Huggins and Davies, (2006, p. 1) define NC as "(...) the capability of an economy to maintain increasing standards of living for those who participate in it, by attracting and maintaining firms with stable or rising market shares in an activity". The International Institute for Management Development (IMD) defines NC as the ability of a nation to create and maintain an environment that sustains more value creation for its enterprises and more prosperity for its people (Garelli, 2012). This definition also associates NC with EP.

Analysing various definitions of NC Bhawsar and Chattopadhyay (2015) conclude that $\mathrm{NC}$ " $(\ldots)$ is the ability of a nation to provide a conducive environment to its firms and hence industries to prosper. The objective is to help in value creation, profit generation and to raise national prosperity at the same time". This definition of NC will be used in this paper.

Academic economists have generally expressed scepticism about the concept of NC. They maintain that NC is based on a weak or non-existent economic 
theory (Lall, 2001; De Grauwe, 2010). Well-known is Krugman's (1994) criticism of NC. He raises three main arguments against $\mathrm{NC}$ of which some were already noted by Porter (1990). ${ }^{6}$

1. Nations do not compete as companies. Whereas an unsuccessful company will ultimately go out of business there is not such an equivalent for nations. "[Countries] may be happy or unhappy with their economic performance but they have no well-defined bottom line. As a result the concept of national competitiveness is elusive."

2. NC is not a 'zero-sum-game'. When companies compete for market share one company's success could be at the cost of other companies. However the success of one country does not destroy the opportunities of other countries.

3. NC is simply another way of saying productivity. However a country's productivity may have nothing to do with competition. Krugman notes that the growth rate of living standards can be "(...) essentially equals the growth rate of domestic productivity, not productivity relative to competitors, but simply domestic productivity. Even though world trade is larger than ever before national living standards are overwhelmingly determined by domestic factors rather than by some competition for world markets".

Krugman's final conclusion is that " $(. .$.$) competitiveness is a meaningless$ word when applied to national economies".

Krugman is right when equating $\mathrm{NC}$ with productivity but this does not preclude the notion of $\mathrm{NC}$ as an enhancer of productivity. In this sense the concept of NC is not a surrogate for productivity but a complementary concept.

\section{The construction of the Global Competitiveness Index}

In the WEF's Global Competitiveness Reports (GCR) GCI aims to measure "(...) the determinants of competitiveness" (Sala-i-Martín \& Schwab, 2017, p. 11). GCI is a composite hierarchical index based on the successive aggregation of scores from the indicator level (the most disaggregated level) up to the overall GCI score. In this paper the indicators are called sub-pillars to preserve a consistent notation. About $30 \%$ of sub-pillars are calculated on the basis of "hard" data, for instance GDP per capita (sub-pillar 10.03). The remaining 70\% of sub-pillars comprise "managers' and experts"” subjective assessments of various aspects of an economy. It is worth adding that the sub-pillars are correlated.

The sub-pillars are aggregated into twelve pillars: 1 . Institutions, 2. Infrastructure, 3. Macroeconomic environment, 4. Health and primary education, 5. Higher education and training, 6. Goods market efficiency, 7. Labour market efficiency, 8. Financial market development, 9. Technological readiness, 10. Market size, 11. Business sophistication and 12. Innovation (Sala-i-Martín

\footnotetext{
${ }^{6}$ It seems that Krugman has overlooked Porter's Competitive advantage of nations (1990).
} 
\& Schwab, 2010, 2011, 2012, 2013, 2014, 2015, 2016, 2017). To make aggregation feasible the sub-pillars are converted to a 1-7 scale. The pillars are the average values of underlying sub-pillars and also take on values on a 1-7 scale.

Next the pillars are aggregated into three indices (hereinafter, "super-pillars"). In GCRs the super-pillars are called Basic requirements, Efficiency enhancers and Innovation and sophistication factors. The stage of a country's economic development forms the basis of such a distinction. Three stages of economic development are distinguished in GCRs: 1. Factor-driven economies, 2. Efficiency-driven economies and 3. Innovation-driven economies. Additionally two transient stages are specified, "from stage 1 to stage 2" and "from stage 2 to stage 3". GDP per capita is the primary criterion of the classification of these stages. In some cases the share of exports represented by raw materials is used as the second criterion of this classification. The Basic requirements super-pillar is the average of four pillars (1-4). The Efficiency enhancers super-pillar is the average of six pillars (5-10). The Innovation and sophistication factors superpillar is the average of two pillars (11-12). Correlations between sub-pillars result in correlations between super-pillars.

Finally GCI is calculated as the weighted average of the super-pillars. The stage-of-development weights are set arbitrarily on the basis of GDP per capita as the leading criterion of the countries' classification (see Table 1 in: Sala-i-Martín \& Schwab, 2010, p. 10).

\section{Selection of sub-pillars}

In this section the WEF's sub-pillars are selected with respect to the definition of NC which was set out in Section 1. Checking whether selected sub-pillars and their aggregates are potential catalysts of productivity is outside the scope of this paper.

The selection of sub-pillars is necessary since they have been compiled for the purpose of the WEF's concept of NC. One may expect that the WEF's data can be also useful when NC is defined in a different way. One may also expect differences between the assessments of NC obtained by two different approaches but based on the same empirical data. Although this is an interesting issue it is not the main goal of this research.

The Bhawsar and Chattopadhyay's (2015) definition of NC is followed, "NC is the ability of a nation to provide a conducive environment to its firms and hence industries, to prosper". Zinnes, Eliat and Sachs (2001, p. 316) provide an additional specification of NC: "Competitiveness is an input into the country's production process that generates the wealth of the nation".

Two empirical consequences can be concluded from the above definitions. First, the actual level of the components of EP expresses the advancement of NC. Second, all components of EP must be of the input-side type. 
Clearly GDP is the output of the national production system. GDP divided by the number of employed workers is the national productivity of labour. WEF applies GDP per capita as the measure of national productivity (see Section 6). $\mathrm{NC}$ as measured by GCI affects productivity from the input side. However GCI, calculated on the basis of all sub-indices, already contains GDP per capita (subpillar 10.03). Some sub-pillars are also 'contaminated' by GDP when they are the indices of the form 'per GDP', or 'a fraction (percent) of GDP'. Moreover GCI is the weighted average of three super-pillars where stage-of-development weights are applied. However these weights are also depend on GDP by a construction. ${ }^{7}$ That artificially improves the image of GCI as a predictor of national productivity. Empirical examples in Section 6 will show some consequences of this methodological drawback of GCI.

One may wonder why this drawback of the WEF's methodology has been overlooked. The reason is that the 'contamination' of sub-pillars by GDP is invisible on the pillar, super-pillar and GCI levels of aggregation of sub-pillars. Although every GCR presents the full list of sub-pillars they are of little interest to a typical user of WEF's rankings. Also researchers are usually not interested in the technical nuances of the analysed indices and rankings.

Taking the above remarks into account the following ten sub-pillars are dropped from the list of 114 sub-pillars. ${ }^{8} 3.01$ Government budget balance, 3.02 National savings rate, 3.03 Inflation, 3.04 Government debt, 3.05 Country credit rating, 6.14 Imports as a percentage of GDP, 10.01 Domestic market size index, 10.02 Foreign market size index, 10.03 GDP per capita valued at PPP, and 10.04 Exports as a percentage of GDP. Hereafter only the remaining 104 sub-pillars will be used in the empirical analysis. Consequently the stage-of-development weights will not be used when calculating some global measures of NC.

PCA as presented in the next Section provides uncorrelated dimensions some of which are combinations of sub-pillars. The resulting dimensions ought to have a convincing economic interpretation which is usually difficult. To facilitate this interpretation a certain classification of sub-pillars is proposed. This classification has a working character and is not an indispensable part of this paper. ${ }^{9}$

Two general subfields of EP are distinguished (see Adamkiewicz, 2017). The first subfield comprises the components of EP which are involved in the feedback-type interactions with individual firms. These are referred to in this subfield of EP as the micro-EP. The second subfield referred to as the macro$E P$ comprises the remaining components of $\mathrm{EP}$ which are not involved in the

${ }^{7}$ In 2018-2019 GCR the stage-of-development weights are abandoned in calculating GCI. Nevertheless GDP is still present among sub-pillars, see i.e. sub-pillar 10.01.

8 The numbering of the sub-pillars is such that the number before a dot specifies the pillar while the number after the dot specifies the consecutive component of the pillar.

9 In the literature there are various classifications of the determinant of NC, see Martin (2004), Glaeser, La Porta, Lopez-de-Silanes and Shleifer (2004), Caselli (2005), Delgado, Porter and Stern (2010), Delgado, Ketels, Porter and Stern (2012). 
feedback interactions with firms ${ }^{10}$. The macro-EP constitutes a general framework of the economic activity of firms (see Adamkiewicz, 2018).

Three parts of the macro-EP can be specified: social, institutional and infrastructural aspects. Since countries compete with each other through various components of EP the terms "social competitiveness", "institutional competitiveness" and "infrastructural competitiveness" may be used. These components of NC comprise the following sub-pillars: Social, Institutional and Infrastructural Competitiveness. Their detailed components are presented in Annex 1.

Micro-EP competitiveness concerns market behaviours of enterprises, their economic decisions and relationships with internal and external stakeholders. The detailed list of sub-pillars components are presented in Annex 2.

Cronbach's alpha (Nunnally, 1978) was used for checking whether the subpillars within a given group measure "the same thing". Note that the sub-pillars ought to be correlated if they are intended to measure the same thing. The higher the correlation between sub-pillars, the more reliable they are in representing the specified group. If the group comprises uncorrelated sub-pillars the coefficient alpha will be equal to zero. If all sub-pillars are perfectly correlated, that is, if they provide full information about the item analysed then the coefficient alpha is equal to 1 . In practice an alpha greater than 0.7 permits a set of items to be determined as a reliable representation of the item measured.

Table 1. Cronbach's alpha for subgroups of competitiveness in 2010-2014

\begin{tabular}{|c|c|c|c|c|c|c|}
\hline $\begin{array}{l}\text { Competi- } \\
\text { tiveness }\end{array}$ & Subgroup & 2010 & 2011 & 2012 & 2013 & 2014 \\
\hline \multirow{3}{*}{ Social } & Health & 0.9165 & 0.9074 & 0.9041 & 0.8951 & 0.8799 \\
\hline & Education & 0.9058 & 0.9071 & 0.8999 & 0.9054 & 0.9046 \\
\hline & Science & 0.9216 & 0.9252 & 0.9168 & 0.9163 & 0.9220 \\
\hline \multirow{3}{*}{ Institutional } & State institutions & 0.9709 & 0.9729 & 0.9719 & 0.9717 & 0.9736 \\
\hline & $\begin{array}{l}\text { Institutional regulations } \\
\text { of markets }\end{array}$ & 0.8001 & 0.8046 & 0.8071 & 0.8177 & 0.8300 \\
\hline & Financial system & 0.9005 & 0.9144 & 0.9143 & 0.9169 & 0.9210 \\
\hline \multirow[b]{2}{*}{ Infrastructural } & Transport & 0.8855 & 0.8859 & 0.8917 & 0.8914 & 0.8779 \\
\hline & $\begin{array}{l}\text { Energy and telecommu- } \\
\text { nication }\end{array}$ & 0.9199 & 0.9128 & 0.9097 & 0.9007 & 0.8946 \\
\hline $\begin{array}{l}\text { Micro-envi- } \\
\text { ronmental }\end{array}$ & & 0.9836 & 0.9845 & 0.9849 & 0.9853 & 0.9855 \\
\hline
\end{tabular}

Source: Own calculations using data from (Sala-i-Martín \& Schwab: 2010, 2011, 2012, 2013, 2014, 2015).

${ }^{10}$ Lobbying and rent-seeking are omitted when explaining the meaning of the macro-environment. 
Table 1 presents the Cronbach's alpha values for the subgroups of competitiveness in 2010-2014. The calculations are performed by the Statistica, the Statsoft package. As seen in Table 2 all coefficient alphas are greater than 0.7. This means that the selected sub-pillars are reliable representatives of the phenomena measured.

\section{The principal component analysis}

The selection of the input-side sub-pillars retains a certain number, say $m$, of correlated EP sub-pillars, $x_{1}, \ldots, x_{m}$. These sub-pillars constitute an $m$-dimensional vector space of NC. If these dimensions were correlated they would partly represent the same information about NC. Occam's razor obliges the researcher to find a minimal number of uncorrelated dimensions. Such uncorrelated dimensions will be called the hidden dimensions of NC.

PCA is applied to determine the hidden dimensions on the basis of environmental components. Since all formal considerations presented in this section come from Jolliffe (2002), except for some notations the citations of certain details will be skipped.

Jolliffie (2002, p. 1) explains the general idea of PCA as: “(...) to reduce the dimensionality of a data set consisting of a large number of interrelated variables while retaining as much as possible of the variation present in the data set. This is achieved by transforming to a new set of variables, the principal components (PCs), which are uncorrelated and which are ordered so that the first few retain most of the variation present in all of the original variables".

In the first step of PCA a linear combination of $m$ sub-pillars $x_{1}, \ldots, x_{m}$ having maximum variance is sought, that is

$$
y_{1}=\alpha_{11} x_{1}+\alpha_{12} x_{2}+\ldots+\alpha_{1 m} x_{m}
$$

$y_{1}$ is the first PC.

The first PC retains some fraction of the total variance. Therefore a linear function is sought

$$
y_{2}=\alpha_{21} x_{1}+\alpha_{22} x_{2}+\ldots+\alpha_{2 m} x_{m}
$$

uncorrelated with $y_{1}$ having maximum variance and so on than at the $k$ stage a linear function

$$
y_{k}=\alpha_{k 1} x_{1}+\alpha_{k 2} x_{2}+\ldots+\alpha_{k m} x_{m}
$$

is found that has maximum variance subject to being uncorrelated with $y_{k-1}$. The $k$ th derived variable (3) is the $k$ th PC. The coefficients $\alpha_{k 1}, \ldots, \alpha_{k m}$ are the load- 
ings of sub-pillars to the $k$ th PC. The variances of the $k$ th PC will be denoted by $\lambda_{k} k=1, \ldots, m \cdot{ }^{11}$ Note that every PC is calculated using all $m$ sub-pillars.

The number of all PCs is equal to the number $m$ of variables. Thus the total variance of all sub-pillars is equal to $\lambda_{1}+\ldots+\lambda_{m}$. However most of the variance in $x_{1}, \ldots, x_{m}$ will usually be accounted for by the first $p$ PCs where $p$ is much less than $m$.

The crucial issue of PCA is the choice of the number $p$ of PCs. Various rules have been proposed in the literature. Although many of them are ad hoc rules of thumb they are commonly used in practice.

The most obvious criterion for determining $p$ consists of selecting a cumulative percentage of total variation and retaining PCs which contribute, say 70 , 80 , or $90 \%$. The percentage of variation accounting for the first $k$ PCs is calculated as below

$$
t_{k}=100 \frac{\sum_{i=1}^{k} \lambda_{i}}{\sum_{i=1}^{m} \lambda_{i}}, \quad k=1, \ldots, m
$$

Other rules for choosing $p$ are based on the screen graph that is the plot of $\lambda_{k}$ against $k$. Looking at the screen plot one must decide at which value of $k$ the slopes of lines connecting the points are 'steep' to the left of $k$ and 'not steep' to the right. This value of $k$, defining an elbow in the graph, is taken to be the number $p$ of PCs to be retained (Jolliffe, 2002, p. 116).

Figure 1 illustrates the screen graph elaborated for sub-pillars 2010. The shape of the graph in Figure 1 seems to be 'flat' after $k$ equals 6 . This means that the six first PCs may be retained.

When correlation matrices are used ${ }^{12}$ the Kaiser' rule (Kaiser, 1960) is commonly used for determining the number of principal components to be retained. Jolliffe (2002, p. 114) explains the idea behind the rule as follows: "If all elements $\left[x_{1}, \ldots, x_{m}\right]$ of $\boldsymbol{x}$ are independent, then PCs are the same as the original variables, and all have unit variances. Thus, any $\mathrm{PC}$ with variance less 1 contains less information than one of the original variables and so is not worth retaining".

It is proposed to apply Kaiser's idea also to consecutive differences $\lambda_{k}-\lambda_{k+1}$, for $k=1, \ldots, m$, bearing in mind that $\lambda_{k}$ is a diminishing sequence of $k$. If, for a certain $k^{\star}$, the difference is less than 1 , the first $k^{\star}$ PCs can be retained. This rule will be referred to as the Kaiser's difference rule.

It is worth noting that PCA is mainly a descriptive technique. This means that there is no need for explicit distributional assumptions. By contrast factor

${ }^{11}$ Formally, $\lambda_{1}, \lambda_{2}, \ldots, \lambda_{m}$ are the eigenvalue of the correlation (covariance) matrix and the vectors of loadings are eigenvectors corresponding to eigenvalues.

12 The correlation matrix is the matrix of the coefficients of correlation between every pair of sub-pillars $y_{1}, \ldots, y_{m}$. The covariance matrix can be also used when finding PCs. 


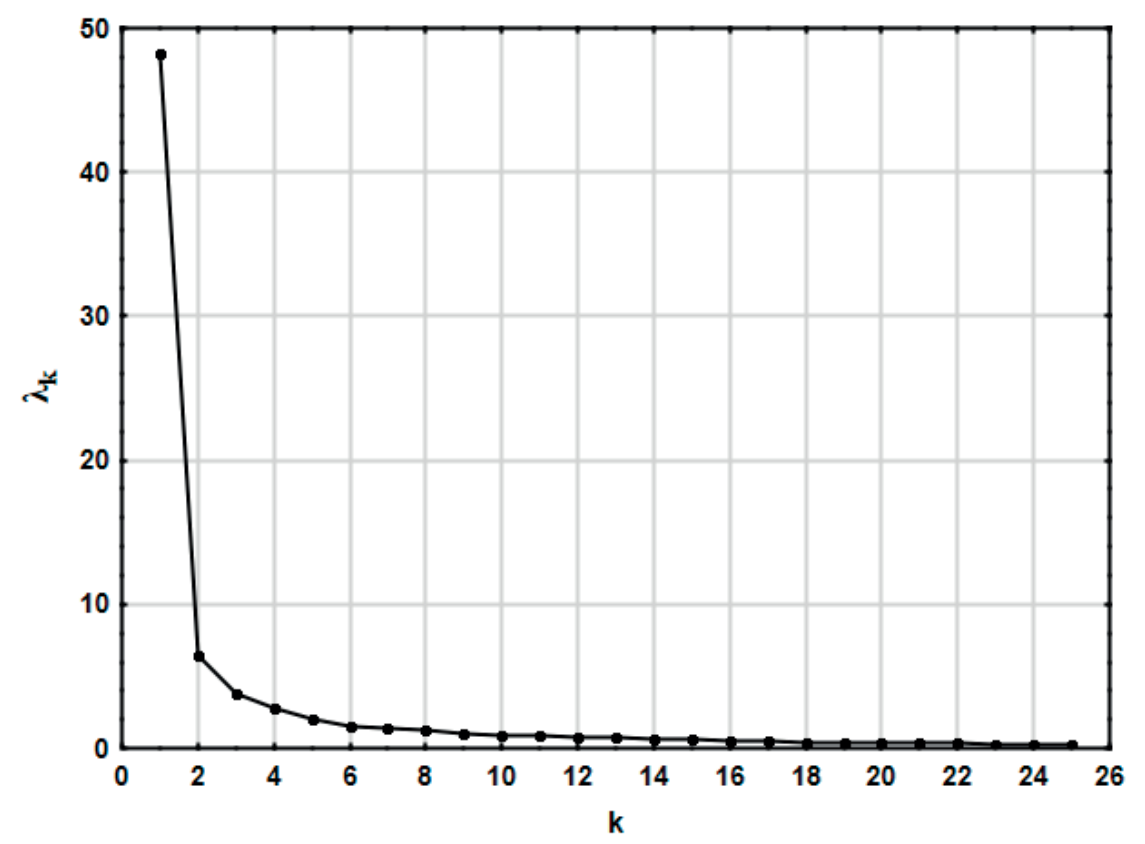

Fig. 1. Screen graph elaborated for EP-sub-pillars 2010

Source: Own elaboration.

analysis, which is often confused with PCA, requires a multivariate normality of variables, an assumption that seems to be unrealistic in many applications.

\section{Empirical results}

The available WEF's data covering the 2008-2015 period were initially taken into account to determine the hidden dimensions of NC. However many gaps in the data made them incomparable across years. After many trials a cohort of complete data for 130 countries and 85 EP sub-pillars for the years 20102014 was completed.

Not all sub-pillars in the cohort of countries provide valuable information about the hidden dimensions. Sub-pillars which are intended to determine a given dimension ought to be strongly correlated with each other but weakly correlated with sub-pillars determining other dimensions. This property of the variables used in PCA is called sampling adequacy and is measured by the Kaiser-Meyer-Olkin (KMO) coefficient (Kaiser, 1974). The KMO coefficient takes on values of between 0 and 1 with small values indicating that, overall, the variables have too little in common to warrant PCA.

The calculation of $\mathrm{KMO}$ for the 85 sub-pillars shows that the four sub-pillars $2.06,7.02,7.03$, and 7.10 , are unacceptable; therefore they were dropped from 
the cohort. For the remaining 81 sub-pillars the overall KMO coefficient was equal to 0.93 in every year, representing the "marvellous" sample adequacy of the selected sub-pillars. ${ }^{13}$

The eigenvalues $\lambda$ of the correlation matrix are calculated with the help of STATA 14.0 software. The use of the correlation matrix over the covariance matrix is dictated by significant differences in the variances of sub-pillars. Table 2 presents the first fifteen of 81 eigenvalues $\lambda$.

Examining Table 2 shows that the eigenvalues are quite stable over the years. The first PC accounts for about $60 \%$ of the total variation of all sub-pillars. The consecutive PCs account for a much smaller and diminishing percent of the total variation as $8,5,4,3$, 2, etc.

Having calculated eigenvalues the number of PCs should be determined. Nine PCs respect Kaiser's rule $(\lambda \geq 1)$ and they account for about $85 \%$ of the total variance of 81 sub-pillars. Looking at the scree graph as in Figure 2 six PCs seem to be worth retaining. They account for about $80 \%$ of the total variance. Three PCs accounting for $70 \%$ of the total variance are retained based on Kaiser's difference rule since adding the fourth $\mathrm{PC}$ increases the cumulative variance by less than one. These three PCs were retained according to the Occam razor. They account for $70 \%$ of the total variance which seems to be acceptable.

The retained PCs ought to have a convincing economic interpretation. For this purpose eigenvectors are used. Although every eigenvector comprises loadings of 81 sub-pillars, some loadings seem to be insignificant (not in the inferential sense). The loadings whose absolute values are greater than 0.1 for the first PC and greater than 0.12 for the remaining PCs are kept. The sub-pillars which appear less than three times in 2010-2014 are dropped.

The choice of the critical values of loadings needs some explanation. When the results of PCA are interpreted it is the general pattern of coefficients that are of interest not values expressed to several decimal places. In practice such a simplification goes even further sometimes retaining only signs $(+/-)$ of eigenvectors (Jolliffe, 2002, p. 66).

Table 3 contains the loadings of sub-pillars to the first PC in 2010-2014. Tables 4 and 5 contain the loadings of sub-pillars to the second and third PCs, respectively. For the sake of clarity every sub-pillar has the symbol which identifies its membership to the group of competitiveness specified earlier, that is, "Inst" - Institutional, "Infr" - Infrastructural, "Soc" - Social, and "Micr" Micro-environmental.

In Table 3 the first principal component (PC1) accounts for about $60 \%$ of the total variance and has positive loadings of roughly equal size to all subpillars. PC1 is dominated by the Institutional sub-pillars (40\%) and Micro-EP sub-pillars (48\%). Two infrastructural sub-pillars and two social sub-pillars

${ }^{13}$ This is the original Kaiser (1974) qualification of sampling adequacy. 


\begin{tabular}{|c|c|c|c|c|c|c|c|c|c|c|c|c|c|c|c|c|}
\hline \multirow{3}{*}{$\stackrel{\nabla}{\stackrel{N}{~}}$} & 空 & $\begin{array}{l}\text { O̊: } \\
0 \\
0\end{array}$ & $\begin{array}{l}\infty \\
0 \\
0 \\
0\end{array}$ & $\begin{array}{c}\stackrel{\infty}{N} \\
\stackrel{0}{0}\end{array}$ & 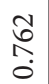 & 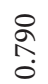 & $\begin{array}{l}\vec{F} \\
\infty \\
0\end{array}$ & $\begin{array}{c}\text { ¿े } \\
\infty \\
0\end{array}$ & $\begin{array}{l}\underset{H}{\infty} \\
\infty \\
0\end{array}$ & $\begin{array}{l}0 \\
\infty \\
\infty \\
0 \\
0\end{array}$ & $\begin{array}{l}\infty \\
\infty \\
\infty \\
0 \\
0\end{array}$ & $\begin{array}{l}\hat{N} \\
\infty \\
0\end{array}$ & $\begin{array}{l}\hat{\alpha} \\
\infty \\
\infty \\
0\end{array}$ & $\begin{array}{l}\stackrel{2}{2} \\
\infty \\
0\end{array}$ & 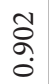 & $\begin{array}{l}\text { } \\
\text { ळे }\end{array}$ \\
\hline & 至 & 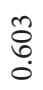 & $\begin{array}{l}\circ \\
\stackrel{0}{0} \\
0\end{array}$ & $\begin{array}{l}\stackrel{0}{0} \\
\stackrel{0}{0}\end{array}$ & ஜே. & $\begin{array}{l}\stackrel{\infty}{\Xi} \\
\stackrel{0}{0}\end{array}$ & $\begin{array}{l}\overrightarrow{\widetilde{\sigma}} \\
\stackrel{0}{0}\end{array}$ & $\begin{array}{c}\infty \\
\stackrel{\infty}{0} \\
0\end{array}$ & 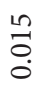 & $\stackrel{m}{\circ}$ & $\stackrel{\sim}{\circ}$ & $\begin{array}{l}\circ \\
0 \\
0\end{array}$ & $\begin{array}{l}\dot{\delta} \\
\dot{0}\end{array}$ & $\begin{array}{l}\infty \\
8 \\
0\end{array}$ & $\begin{array}{l}\hat{8} \\
\stackrel{0}{0}\end{array}$ & $\begin{array}{l}1 \\
\text { ᄋ̊ } \\
\dot{0}\end{array}$ \\
\hline & 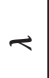 & $\begin{array}{l}0 \\
\infty \\
\infty \\
\infty \\
+\infty\end{array}$ & $\underset{g}{\stackrel{g}{0}}$ & $\underset{\dot{r}}{\dot{n}}$ & $\stackrel{\widehat{N}}{\mathrm{i}}$ & $\stackrel{\widehat{N}}{\mathrm{~N}}$ & $\stackrel{N}{\curvearrowright}$ & $\underset{-}{\stackrel{H}{-}}$ & 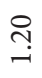 & 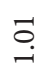 & $\stackrel{\check{o}}{o}$ & $\stackrel{N}{\hat{O}}$ & $\begin{array}{l}n \\
\stackrel{0}{0}\end{array}$ & $\begin{array}{l}\infty \\
\stackrel{0}{0} \\
0\end{array}$ & 啇 & 葛 \\
\hline \multirow{3}{*}{ 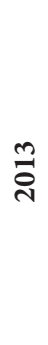 } & 空 & $\begin{array}{l}\text { Ln } \\
\text { రి } \\
0\end{array}$ & $\begin{array}{l}\infty \\
\infty \\
0 \\
0 \\
0\end{array}$ & 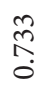 & $\begin{array}{l}\text { Jో } \\
\stackrel{0}{0}\end{array}$ & 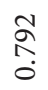 & $\begin{array}{l}m \\
\infty \\
0\end{array}$ & $\begin{array}{c}\vec{\infty} \\
\infty \\
\dot{0}\end{array}$ & $\stackrel{\text { f }}{\infty}$ & $\begin{array}{l}8 \\
\infty \\
0 \\
0\end{array}$ & $\begin{array}{c}\mathbb{1} \\
\infty \\
0\end{array}$ & $\begin{array}{l}\vec{\infty} \\
\infty \\
0 \\
0\end{array}$ & $\begin{array}{l}2 \\
\infty \\
\infty \\
0\end{array}$ & $\begin{array}{l}\hat{\alpha} \\
\infty \\
0 \\
0\end{array}$ & 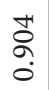 & $\begin{array}{l}\bar{\sigma} \\
\dot{0}\end{array}$ \\
\hline & 至 & $\begin{array}{l}n \\
0 \\
0 \\
0\end{array}$ & $\begin{array}{l}n \\
0 \\
0 \\
0\end{array}$ & 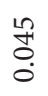 & $\begin{array}{l}\tilde{\sigma} \\
\tilde{0}\end{array}$ & $\begin{array}{l}\widehat{\widehat{O}} \\
0 \\
0\end{array}$ & 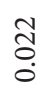 & $\begin{array}{c}\infty \\
\stackrel{\infty}{0} \\
\dot{0}\end{array}$ & $\begin{array}{l}0 \\
\stackrel{0}{0} \\
0\end{array}$ & $\stackrel{m}{\circ}$ & $\stackrel{7}{\sigma}$ & $\begin{array}{l}\circ \\
0 \\
0 \\
0\end{array}$ & $\begin{array}{l}\dot{\delta} \\
\dot{0}\end{array}$ & $\begin{array}{l}\infty \\
\stackrel{8}{\circ} \\
\stackrel{0}{0}\end{array}$ & $\begin{array}{l}\hat{8} \\
\stackrel{\circ}{\circ}\end{array}$ & $\begin{array}{l}8 \\
8 \\
\circ\end{array}$ \\
\hline & 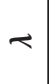 & 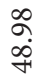 & $\underset{\sigma}{\stackrel{N}{0}}$ & $\begin{array}{l}\hat{b} \\
\dot{n}\end{array}$ & 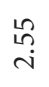 & $\underset{i}{\stackrel{a}{i}}$ & 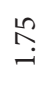 & $\stackrel{\stackrel{\leftrightarrow}{-}}{-}$ & సָ & 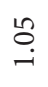 & $\vec{\sigma}$ & $\begin{array}{l}\vec{\infty} \\
\dot{0}\end{array}$ & $\begin{array}{l}\hat{b} \\
\dot{0}\end{array}$ & $\begin{array}{l}\tilde{O} \\
\dot{0}\end{array}$ & in? & $\begin{array}{l}0 \\
\text { !n } \\
0\end{array}$ \\
\hline \multirow{3}{*}{ 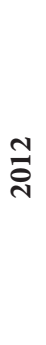 } & 空 & $\begin{array}{l}\text { ô } \\
\text { o. } \\
0\end{array}$ & $\begin{array}{l}m \\
\infty \\
0 \\
0\end{array}$ & 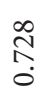 & $\begin{array}{l}\overrightarrow{0} \\
\stackrel{0}{0}\end{array}$ & $\begin{array}{l}\infty \\
\infty \\
\stackrel{0}{0} \\
0\end{array}$ & $\begin{array}{l}\infty \\
\stackrel{0}{0} \\
0 \\
0\end{array}$ & $\begin{array}{l}\stackrel{L}{2} \\
\infty \\
0 \\
0\end{array}$ & $\begin{array}{l}\vec{F} \\
\stackrel{\infty}{0} \\
0\end{array}$ & $\begin{array}{l}\text { H' } \\
\infty \\
0 \\
0\end{array}$ & $\begin{array}{l}8 \\
\varnothing \\
0 \\
0\end{array}$ & 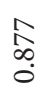 & $\begin{array}{l}10 \\
\infty \\
\infty \\
0\end{array}$ & $\begin{array}{l}\text { مू } \\
\text { ’ }\end{array}$ & $\begin{array}{l}\stackrel{\$}{\circ} \\
\stackrel{\circ}{ }\end{array}$ & ڤ̊ \\
\hline & 饪 & 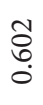 & $\begin{array}{l}\infty \\
0 \\
0\end{array}$ & \begin{tabular}{l}
\multirow{H}{*}{} \\
$\stackrel{0}{0}$
\end{tabular} & $\begin{array}{l}\text { ले } \\
\stackrel{0}{0}\end{array}$ & $\begin{array}{l}\stackrel{0}{1} \\
\text { o. }\end{array}$ & $\begin{array}{l}\overrightarrow{\widehat{C}} \\
\stackrel{0}{0}\end{array}$ & $\begin{array}{l}\stackrel{-}{o} \\
\stackrel{\circ}{0}\end{array}$ & $\begin{array}{l}10 \\
0 \\
0\end{array}$ & $\stackrel{m}{\circ}$ & 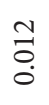 & $\stackrel{\square}{\sigma}$ & $\begin{array}{l}\infty \\
\stackrel{0}{0} \\
0\end{array}$ & $\begin{array}{l}\infty \\
\stackrel{8}{0} \\
0\end{array}$ & $\begin{array}{l}\infty \\
\stackrel{8}{0} \\
\stackrel{0}{0}\end{array}$ & $\begin{array}{l}1 \\
\stackrel{8}{0} \\
0\end{array}$ \\
\hline & 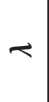 & $\begin{array}{l}\infty \\
\infty \\
\infty \\
\infty\end{array}$ & 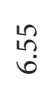 & ڤṇ & $\underset{\mathrm{N}}{\stackrel{N}{N}}$ & $\underset{i}{\stackrel{H}{i}}$ & $\stackrel{\widehat{\sigma}}{\circ}$ & $\stackrel{\infty}{\dddot{m}}$ & $\stackrel{\overbrace{}}{\stackrel{n}{H}}$ & $\stackrel{\infty}{\circ}$ & $\stackrel{n}{\varrho}$ & $\begin{array}{l}\infty \\
0 \\
0\end{array}$ & $\hat{0}$ & ర్ర & $\stackrel{\vec{b}}{0}$ & กֶ? \\
\hline \multirow{3}{*}{$\overline{\mathrm{D}}$} & 密 & $\begin{array}{l}\overrightarrow{0} \\
\dot{0} \\
\dot{0}\end{array}$ & $\begin{array}{l}\sqrt{0} \\
0 \\
0 \\
0\end{array}$ & $\begin{array}{c}\stackrel{\infty}{N} \\
\stackrel{0}{0}\end{array}$ & 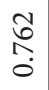 & $\begin{array}{l}\infty \\
\infty \\
\\
0\end{array}$ & $\begin{array}{l}1 \\
\text { o } \\
0 \\
0\end{array}$ & 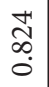 & $\begin{array}{l}\text { ळे } \\
\infty \\
0\end{array}$ & $\begin{array}{l}\text { N } \\
\infty \\
0 \\
0\end{array}$ & $\begin{array}{l}\text { J } \\
\infty \\
0\end{array}$ & $\begin{array}{l}+ \\
\infty \\
\infty \\
0\end{array}$ & $\begin{array}{l}m \\
\infty \\
\infty \\
0\end{array}$ & $\begin{array}{l}\vec{\sigma} \\
\infty \\
\dot{0}\end{array}$ & $\begin{array}{l}\infty \\
\infty \\
\infty \\
0\end{array}$ & $\begin{array}{l}\text { Ln } \\
\text { ᄋ़ } \\
0\end{array}$ \\
\hline & 至 & $\begin{array}{l}\tilde{0} \\
\stackrel{0}{0} \\
0\end{array}$ & $\begin{array}{l}\infty \\
0 \\
0\end{array}$ & $\begin{array}{l}\text { Fे } \\
\text { Oे }\end{array}$ & ڤે & $\begin{array}{l}\stackrel{0}{1} \\
\text { o. } \\
\stackrel{0}{0}\end{array}$ & $\stackrel{\circ}{\stackrel{\sigma}{0}}$ & $\begin{array}{l}1 \\
0 \\
0 \\
0\end{array}$ & $\stackrel{10}{0}$ & $\stackrel{\sim}{1}$ & $\stackrel{\sim}{a}$ & 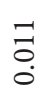 & $\begin{array}{l}\dot{8} \\
\dot{0}\end{array}$ & $\begin{array}{l}\infty \\
\stackrel{8}{8} \\
\stackrel{0}{0}\end{array}$ & $\begin{array}{l}\hat{8} \\
\stackrel{0}{\circ}\end{array}$ & $\begin{array}{l}\hat{8} \\
\text { ○े }\end{array}$ \\
\hline & 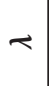 & $\begin{array}{l}10 \\
\infty \\
\infty \\
+\end{array}$ & 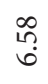 & $\begin{array}{l}\infty \\
\stackrel{\infty}{m}\end{array}$ & $\stackrel{m}{\stackrel{n}{i}}$ & $\begin{array}{l}\infty \\
\stackrel{\infty}{i} \\
\text { in }\end{array}$ & $\stackrel{n}{i}$ & $\stackrel{n}{m}$ & 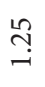 & $\stackrel{8}{8}$ & مิ & $\begin{array}{l}\infty \\
\infty \\
0\end{array}$ & $\overrightarrow{\widehat{0}}$ & $\begin{array}{l}n \\
\stackrel{1}{0} \\
0\end{array}$ & 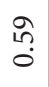 & in? \\
\hline \multirow{3}{*}{ 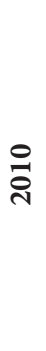 } & $\vec{\omega}$ & $\begin{array}{l}\text { مे } \\
\text { ஸे } \\
0\end{array}$ & $\begin{array}{l}0 \\
\hat{b} \\
0\end{array}$ & $\underset{\stackrel{N}{N}}{\stackrel{N}{0}}$ & $\begin{array}{l}\stackrel{\infty}{\stackrel{n}{n}} \\
\vdots \\
0\end{array}$ & $\begin{array}{l}\infty \\
\infty \\
0 \\
0\end{array}$ & $\begin{array}{l}\widetilde{1} \\
\infty \\
0 \\
0\end{array}$ & $\begin{array}{c}a \\
\stackrel{\infty}{0} \\
\stackrel{0}{0}\end{array}$ & $\begin{array}{c}0 \\
\infty \\
\infty \\
0 \\
0\end{array}$ & $\begin{array}{l}\infty \\
+ \\
\infty \\
0\end{array}$ & $\begin{array}{l}8 \\
\infty \\
0 \\
0\end{array}$ & $\begin{array}{c}\stackrel{0}{\infty} \\
\infty \\
0\end{array}$ & $\begin{array}{l}\stackrel{\hat{\imath}}{\infty} \\
0 \\
0\end{array}$ & $\begin{array}{l}\infty \\
\infty \\
\infty \\
0 \\
0\end{array}$ & $\begin{array}{l}\circ \\
\infty \\
\stackrel{0}{0}\end{array}$ & 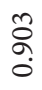 \\
\hline & 至 & $\begin{array}{l}\text { ڤ̊ } \\
\text { 彳े? }\end{array}$ & $\begin{array}{l}0 \\
0 \\
0 \\
0\end{array}$ & \begin{tabular}{l}
0 \\
\multirow{0}{0}{} \\
$\stackrel{0}{0}$
\end{tabular} & $\stackrel{n}{\tilde{o}}$ & $\begin{array}{l}\text { o } \\
\text { ర్ } \\
\stackrel{0}{0}\end{array}$ & $\begin{array}{l}a \\
\stackrel{0}{0} \\
\ddot{0}\end{array}$ & $\stackrel{\curvearrowright}{\circ}$ & $\begin{array}{l}0 \\
\stackrel{0}{0} \\
\stackrel{0}{0}\end{array}$ & $\stackrel{m}{\circ}$ & $\stackrel{7}{\vec{\sigma}}$ & $\stackrel{7}{\vec{\sigma}}$ & Oे̊ & $\begin{array}{l}\stackrel{0}{0} \\
\dot{0}\end{array}$ & $\begin{array}{l}\infty \\
\stackrel{0}{0} \\
0\end{array}$ & $\begin{array}{l}1 \\
\stackrel{0}{0}\end{array}$ \\
\hline & $\rightarrow$ & $\begin{array}{l}\hat{y} \\
\infty \\
+\end{array}$ & $\underset{\sigma}{\stackrel{f}{0}}$ & $\begin{array}{l}\stackrel{2}{N} \\
\dot{m}\end{array}$ & $\begin{array}{l}\infty \\
\stackrel{\sim}{i}\end{array}$ & $\begin{array}{l}\text { o } \\
\text { i }\end{array}$ & $\stackrel{n}{n}$ & 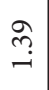 & $\stackrel{\overbrace{}}{\text { กี }}$ & 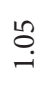 & 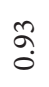 & $\begin{array}{l}10 \\
\infty \\
0 \\
0\end{array}$ & $\stackrel{n}{\stackrel{0}{0}}$ & $\stackrel{N}{\stackrel{N}{0}}$ & $\begin{array}{l}\overrightarrow{0} \\
\dot{0}\end{array}$ & $\begin{array}{l}\infty \\
n \\
0 \\
0\end{array}$ \\
\hline & & - & $\sim$ & $m$ & $r$ & in & 0 & $\wedge$ & $\infty$ & $a$ & $\stackrel{-}{\circ}$ & $\exists$ & $\simeq$ & $\stackrel{m}{=}$ & 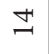 & $\stackrel{2}{\sim}$ \\
\hline
\end{tabular}


Table 3. First principal component: Eigenvectors in 2010-2014

\begin{tabular}{|c|c|c|c|c|c|c|}
\hline Sub-pillar & Symbol & 2010 & 2011 & 2012 & 2013 & 2014 \\
\hline 0101 Property rights & Inst & 0.13 & 0.13 & 0.13 & 0.13 & 0.13 \\
\hline 0102 Intellectual property protection & Inst & 0.13 & 0.13 & 0.13 & 0.13 & 0.14 \\
\hline 0103 Diversion of public funds & Inst & 0.13 & 0.13 & 0.13 & 0.12 & 0.12 \\
\hline 0105 Irregular payments et bribes & Inst & 0.13 & 0.13 & 0.13 & 0.13 & 0.13 \\
\hline 0106 Judicial independence & Inst & 0.13 & 0.13 & 0.13 & 0.12 & 0.12 \\
\hline $\begin{array}{l}0110 \text { Efficiency of legal framework in settling } \\
\text { disputes }\end{array}$ & Inst & 0.12 & & & 0.12 & 0.12 \\
\hline $\begin{array}{l}0111 \text { Efficiency of legal framework in chal- } \\
\text { lenging regulations }\end{array}$ & Inst & 0.12 & & 0.12 & 0.12 & \\
\hline 0116 Reliability of police services & Inst & 0.12 & 0.12 & 0.13 & 0.12 & 0.12 \\
\hline $\begin{array}{l}0120 \text { Protection of minority shareholders' } \\
\text { interests }\end{array}$ & Inst & & & 0.12 & 0.12 & 0.12 \\
\hline 0603 Effectiveness of anti-monopoly policy & Inst & 0.13 & 0.13 & 0.12 & 0.12 & 0.13 \\
\hline 0613 Burden of customs procedures & Inst & & & 0.12 & 0.12 & 0.13 \\
\hline 0801 Availability of financial services & Inst & 0.12 & 0.13 & 0.12 & 0.13 & 0.13 \\
\hline 0802 Affordability of financial services & Inst & 0.12 & 0.12 & 0.12 & 0.13 & 0.13 \\
\hline 0201 Quality of overall infrastructure & Infr & 0.12 & 0.13 & 0.13 & 0.13 & 0.13 \\
\hline 0205 Quality of air transport infrastructure & Infr & & 0.12 & 0.12 & 0.12 & 0.12 \\
\hline 0117 Ethical behaviour of firms & Micr & 0.13 & 0.13 & 0.13 & 0.13 & 0.13 \\
\hline $\begin{array}{l}0118 \text { Strength of auditing et reporting stan- } \\
\text { dards }\end{array}$ & Micr & 0.12 & 0.12 & 0.12 & 0.12 & 0.12 \\
\hline $\begin{array}{l}0507 \text { Local availability of specialized research } \\
\text { et training services }\end{array}$ & Micr & 0.13 & 0.13 & 0.13 & 0.13 & 0.13 \\
\hline 0508 Extent of staff training & Micr & 0.13 & 0.13 & 0.13 & 0.13 & 0.13 \\
\hline 0615 Degree of customer orientation & Micr & 0.12 & 0.12 & 0.12 & & \\
\hline 0616 Buyer sophistication & Micr & 0.12 & 0.12 & 0.12 & 0.12 & 0.12 \\
\hline 0707 Reliance on professional management & Micr & 0.12 & 0.13 & 0.13 & 0.13 & 0.13 \\
\hline 0901 Availability of latest technologies & Micr & 0.13 & 0.13 & 0.13 & 0.13 & 0.13 \\
\hline 0902 Firm-level technology absorption & Micr & 0.13 & 0.13 & 0.13 & 0.13 & 0.13 \\
\hline 1102 Local supplier quality & Micr & 0.13 & 0.13 & 0.13 & 0.13 & 0.13 \\
\hline 1105 Value chain breadth & Micr & 0.12 & 0.12 & 0.12 & 0.12 & 0.12 \\
\hline 1107 Production process sophistication & Micr & 0.13 & 0.13 & 0.13 & 0.13 & 0.13 \\
\hline 1108 Extent of marketing & Micr & 0.13 & 0.13 & 0.13 & 0.13 & 0.13 \\
\hline 1109 Willingness to delegate authority & Micr & 0.12 & 0.13 & 0.13 & 0.12 & 0.13 \\
\hline 1201 Capacity for innovation & Micr & & 0.12 & & 0.12 & 0.12 \\
\hline 1203 Company spending on $\mathrm{R} \& \mathrm{D}$ & Micr & & & 0.12 & 0.12 & 0.12 \\
\hline 1202 Quality of scientific research institutions & Soc & 0.12 & 0.12 & 0.12 & 0.12 & 0.12 \\
\hline $\begin{array}{l}1204 \text { University-industry collaboration in } \\
\text { R\&D }\end{array}$ & Soc & 0.13 & 0.13 & 0.13 & 0.13 & 0.13 \\
\hline
\end{tabular}

Note: Symbols of the competitiveness groups: Inst - Institutional; Infr - Infrastructure factors; Soc - Social; Micr - Micro-environment.

Source: Own calculations. 
Table 4. Second principal component: Eigenvectors in 2010-2014

\begin{tabular}{|c|c|c|c|c|c|c|c|}
\hline Code & Sub-pillar & Symbol & 2010 & 2011 & 2012 & 2013 & 2014 \\
\hline \multicolumn{2}{|c|}{0108 Wastefulness of government spending } & Inst & -0.22 & -0.21 & & & -0.20 \\
\hline \multicolumn{2}{|c|}{0109 Burden of government regulation } & Inst & -0.25 & -0.26 & -0.25 & -0.26 & -0.27 \\
\hline \multicolumn{2}{|c|}{0209 Fixed telephone lines } & Infr & & & 0.21 & 0.21 & 0.21 \\
\hline \multicolumn{2}{|c|}{0404 Tuberculosis incidence } & Soc & & 0.20 & 0.22 & 0.21 & 0.21 \\
\hline \multicolumn{2}{|c|}{0406 HIV prevalence } & Soc & 0.21 & 0.22 & 0.23 & 0.22 & 0.21 \\
\hline \multicolumn{2}{|c|}{0407 Infant mortality } & Soc & 0.21 & 0.22 & 0.22 & 0.21 & \\
\hline \multicolumn{2}{|c|}{0408 Life expectancy } & Soc & 0.22 & 0.23 & 0.24 & 0.24 & 0.23 \\
\hline \multicolumn{2}{|c|}{0501 Secondary education enrolment rate } & Soc & 0.20 & 0.21 & 0.22 & 0.22 & 0.21 \\
\hline \multicolumn{2}{|c|}{0502 Tertiary education enrolment rate } & Soc & 0.26 & 0.26 & 0.26 & 0.26 & 0.28 \\
\hline
\end{tabular}

Note: see Table 3 for the description of symbols.

Source: Own calculations.

account for the remaining $4 \%$ of 33 sub-pillars. Thus PC1 can be interpreted as the Institutional and micro-environmental potential of NC.

In Table 4 the second principal component (PC2) accounts for $8 \%$ of the total variance and therefore it is much less important than $\mathrm{PC} 1$ in determining $\mathrm{NC}$. PC2 contrasts government efficiency with health and education. The presence of one infrastructural sub-pillar (Fixed telephone lines) in PC2 in 2012-2014 is unclear. PC2 might be called Government efficiency in health and education.

Table 5. Third principal component: Eigenvectors in 2010-2014

\begin{tabular}{|l|c|c|c|c|c|c|c|}
\hline Code & Sub-pillar & Symbol & $\mathbf{2 0 1 0}$ & $\mathbf{2 0 1 1}$ & $\mathbf{2 0 1 2}$ & $\mathbf{2 0 1 3}$ & $\mathbf{2 0 1 4}$ \\
\hline 0113 Business costs of terrorism & Inst & 0.25 & 0.25 & 0.25 & 0.26 & 0.28 \\
\hline 0114 Business costs of crime et violence & Inst & 0.30 & 0.31 & 0.31 & 0.31 & 0.31 \\
\hline 0115 Organized crime & Inst & 0.26 & 0.26 & 0.28 & 0.30 & 0.31 \\
\hline 1101 Local supplier quantity & Micr & -0.23 & -0.21 & -0.22 & -0.23 & -0.24 \\
\hline
\end{tabular}

Note: see Table 3 for the description of symbols.

Source: Own calculations.

In Table 5 the third principal component (PC3) accounts for about 5\% of the total variance of sub-pillars; therefore it is less important than both PC1 and PC2 in determining NC. PC3 contrasts business sophistication (sub-pillar: Local supplier quantity) with public security. This can be called PC the Public security of business. 
PCA reveals three hidden orthogonal (uncorrelated) dimensions of NC in 2010-2014. Among these dimensions PC1, the Institutional and micro-environmental potential of $\mathrm{NC}$ is the most important. The second dimension PC2, Government efficiency in health and education is much less important in the explanation of NC. The third dimension PC3, Public security of business is of the least importance. These three dimensions account for $70 \%$ of information contained in all 81 sub-pillars.

To make the principal components comparable with GCI the calculated PCs were transformed to 1-7 scale according to the formula

$$
P C_{l i}=1+6 \frac{y_{l i}-y_{\min }}{y_{\max }-y_{\min }},
$$

where $y_{l i}$ is the $l$ th PC for $i$ th country, and $y_{l \min }$ and $y_{l \max }$ are minimum and maximum values of $i$ th PC in the sample of countries, respectively.

Figure 2 shows the location of countries in the three-dimensional space (PC1, PC2, PC3) for 2014.

In Figure 2 the $i$ th point, with coordinates $\left(p c_{1 i}, p c_{2 i}, p c_{3 i}\right)$, represents $i$ th country. Point $(1,1,1)$, the origin of the coordinates represents a country that has

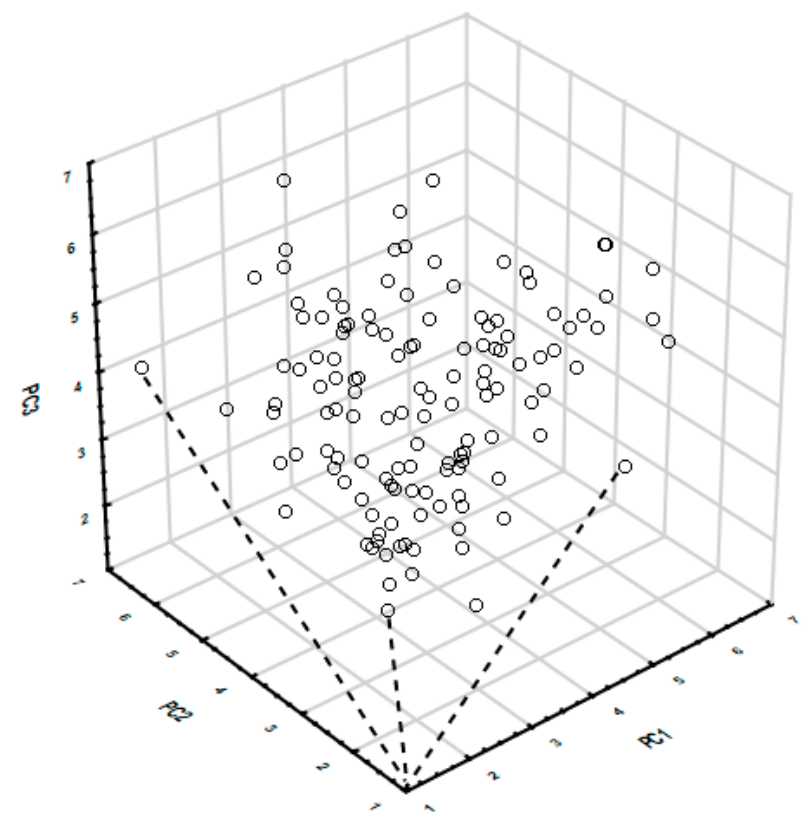

Figure 2. Countries in 3-dimensional space of principal components in 2014. Dotted lines illustrate the distance from the origin as the measure of $\mathrm{NC}$

Source: Own elaboration. 
minimum scores in all dimensions whereas point $(7,7,7)$ represents a country that has attained maximum scores. Thus the distance between the origin and point $\left(p c_{1 i}, p c_{2 i}, p c_{3 i}\right)$ (dotted lines in Figure 3) can be taken as the measure of $i$ th country's NC, that is $i$ th country's actual achievement in providing an attractive environment for firms.

In the general case of $p$ dimensions the distance can be measured by the weighted Euclidian distance of the form

$$
p D w=\left[\sum_{l=1}^{p} w_{l}\left(P C_{l}-1\right)^{2}\right]^{1 / 2},
$$

where weight $w_{l}$ is the variance share of the of $l$ th PC, that is, the ratio of eigenvalue $\lambda_{p}$ and the sum of $p$ eigenvalues

$$
w_{l}=\frac{\lambda_{l}}{\sum_{l=1}^{p} \lambda_{l}}, \quad l=1, \ldots, p .
$$

Both the need for weighting PC dimensions and the form (9) of weights are due to the nature of PCA; it produces consecutive PCs of a diminishing (nonequal) importance. Weighted Euclidian distance is commonly used in multidimensional scaling (see i.e. Cox, 2001, p. 206).

Thus $3 \mathrm{Dw}$ will be the global index of NC based on $p=3$ PCs. Note that weights $w_{l}(9)$ are calculated on the basis of estimated eigenvalues in contrast to arbitrary the stage-of-development weights which are used for calculating GCI.

The three principal components and the 3Dw measure of $\mathrm{NC}$ can be used as proxies of the catalysts of productivity in the A-K model. This will be the topic of further research.

\section{Rankings of countries}

The rankings of 130 countries in 2014 according to $3 D w$ and $\mathrm{GCI}_{\mathrm{ESP}}$ are calculated. The latter index is the mean of EP-sub-pillars presented in Section 3. The rankings are also calculated according to national productivity (as explained below), GCI and GDP. Before presenting the rankings the problem of the measurement of productivity is discussed.

In GCRs the productivity (of labour) is measured by GDP per capita. ${ }^{14}$ It is maintained that GCI explains two thirds of variation of productivity (Sala-i-Martín \& Schwab, 2014, pp. 46-48).

\footnotetext{
${ }^{14}$ Data on the GDP per capita come from the International Monetary Fund database (Salai-Martín \& Schwab, 2014).
} 
However GDP per capita, as measured by the International Monetary Fund IMF, or that presented-for over four decades-in the Penn World Table (PWT) is a poor indicator of labour productivity of a country. It is close to the PWT's concept of GDP on the expenditure side (GDP $)$. GDP $\mathrm{e}^{\mathrm{e}}$, or its components such as consumption and domestic absorption have been intended to measure the standard of living across countries rather than productivity (Feenstra, Inklaar, \& Timmer, 2009). GDP ${ }^{e}$ does not remarkably differ from the IMF's GDP.

A better base for measuring labour productivity is GDP on the output side $\left(\mathrm{GDP}^{\circ}\right)$. The concept of $\mathrm{GDP}^{\circ}$, initiated by the new PWT team is intended to measure the productive capacity of an economy (Feenstra et al., 2015). Thus real $\mathrm{GDP}^{\circ}$, divided by the number of persons engaged (variable emp in PWT 9.0 ) is the proper measure of a country's labour productivity. This indicator of labour productivity is referred to as the real GDP per worker.

Figure 3 displays the distribution of three versions of GDP among GCR countries in 2014: IMF's GDP per capita (used by GCRs), real GDP ${ }^{\mathrm{e}}$ per capita and real GDP ${ }^{\circ}$ per worker. For the sake of brevity the qualification "real" is omitted. The density functions presented in Figure 3 are estimated by Gaussian kernels and expressed on the logarithmic scale. Figure 3 shows that the distributions of GDP per capita and GDP ${ }^{\mathrm{e}}$ per capita are close to each other but far from the distribution of labour productivity.

Table 6 presents rankings and scores of countries in 2014 according to $3 D w$, $\mathrm{GDP}^{\mathrm{o}}$ per worker GCI and GDP. Additional ranking bases on the index $\mathrm{GCI}_{\mathrm{ESP}}$

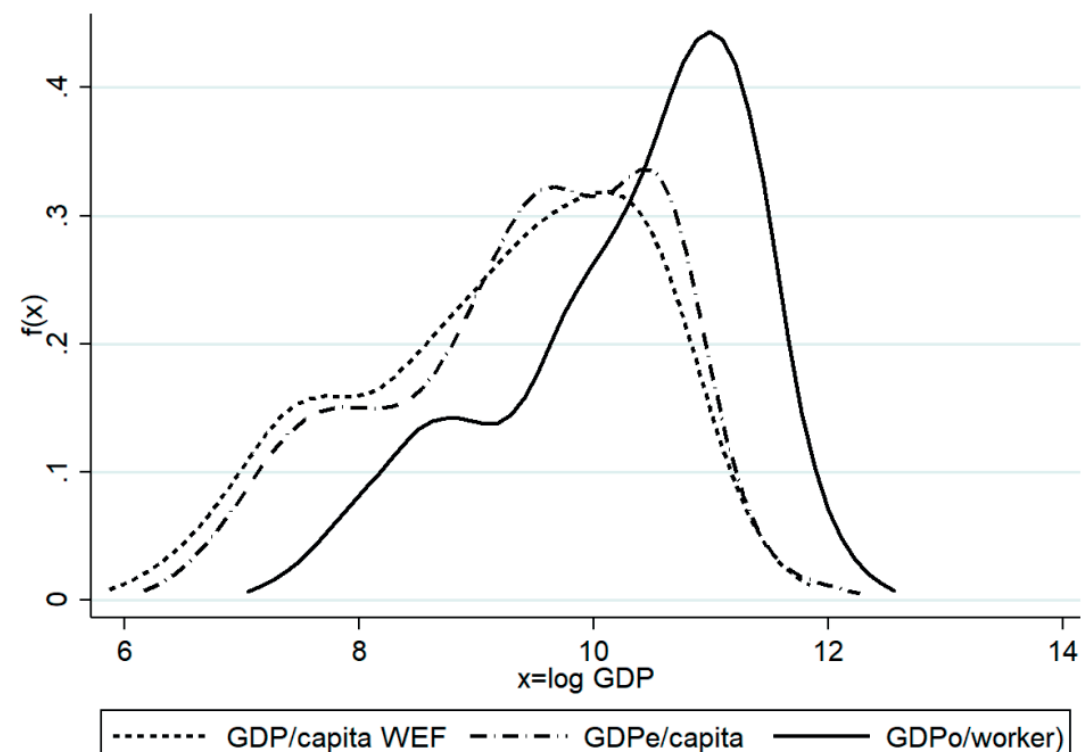

Figure 3. The distributions of GDP per capita (WEF), GDP ${ }^{\mathrm{e}}$ per capita and GDP ${ }^{\mathrm{o}}$ per worker in 2014

Source: Own elaboration using data from PWT8.0 and WEF. 
Table 6. Rankings and scores in 2014 (top 55 countries)

\begin{tabular}{|c|c|c|c|c|c|c|c|c|}
\hline \multirow[t]{2}{*}{ Country } & \multicolumn{2}{|c|}{ 3Dw } & \multicolumn{2}{|c|}{$\mathbf{G C I}_{\mathrm{ESP}}$} & \multirow{2}{*}{$\begin{array}{c}\begin{array}{c}\mathrm{GDP}^{0} / \\
\text { emp }\end{array} \\
\text { Rank }\end{array}$} & \multicolumn{2}{|c|}{ GCI } & \multirow{2}{*}{$\begin{array}{c}\text { GDP/ } \\
\text { capita } \\
\text { Rank }\end{array}$} \\
\hline & Rank & Score & Rank & Score & & Rank & Score & \\
\hline Finland & 1 & 5.30 & 3 & 5.52 & 24 & 4 & 5.50 & 22 \\
\hline Singapore & 2 & 5.28 & 1 & 5.61 & 7 & 2 & 5.65 & 3 \\
\hline Switzerland & 3 & 5.24 & 2 & 5.54 & 9 & 1 & 5.70 & 7 \\
\hline Qatar & 4 & 5.13 & 4 & 5.46 & 1 & 16 & 5.24 & 1 \\
\hline Netherlands & 5 & 5.02 & 7 & 5.38 & 11 & 8 & 5.45 & 11 \\
\hline $\begin{array}{l}\text { United Arab } \\
\text { Emirates }\end{array}$ & 6 & 4.98 & 8 & 5.38 & 8 & 12 & 5.33 & 30 \\
\hline New Zealand & 7 & 4.96 & 6 & 5.39 & 35 & 17 & 5.20 & 26 \\
\hline Hong Kong SAR & 8 & 4.89 & 5 & 5.40 & 18 & 7 & 5.46 & 5 \\
\hline Japan & 9 & 4.88 & 11 & 5.28 & 30 & 6 & 5.47 & 21 \\
\hline Luxembourg & 10 & 4.87 & 9 & 5.31 & 15 & 19 & 5.17 & 2 \\
\hline Norway & 11 & 4.85 & 10 & 5.29 & 2 & 11 & 5.35 & 4 \\
\hline Sweden & 12 & 4.76 & 14 & 5.25 & 21 & 10 & 5.41 & 13 \\
\hline United Kingdom & 13 & 4.73 & 13 & 5.25 & 25 & 9 & 5.41 & 20 \\
\hline Germany & 14 & 4.69 & 15 & 5.18 & 16 & 5 & 5.49 & 16 \\
\hline United States & 15 & 4.67 & 12 & 5.26 & 6 & 3 & 5.54 & 6 \\
\hline Belgium & 16 & 4.60 & 20 & 5.08 & 12 & 18 & 5.18 & 18 \\
\hline Malaysia & 17 & 4.53 & 19 & 5.10 & 57 & 20 & 5.16 & 51 \\
\hline Canada & 18 & 4.52 & 16 & 5.13 & 23 & 15 & 5.24 & 8 \\
\hline Denmark & 19 & 4.51 & 18 & 5.11 & 14 & 13 & 5.29 & 19 \\
\hline Taiwan, China & 20 & 4.47 & 17 & 5.11 & 20 & 14 & 5.25 & 17 \\
\hline Ireland & 21 & 4.47 & 21 & 5.06 & 4 & 25 & 4.98 & 14 \\
\hline Austria & 22 & 4.43 & 22 & 4.98 & 17 & 21 & 5.16 & 9 \\
\hline Australia & 23 & 4.23 & 23 & 4.92 & 19 & 22 & 5.08 & 10 \\
\hline Iceland & 24 & 4.17 & 24 & 4.85 & 29 & 30 & 4.71 & 15 \\
\hline France & 25 & 4.11 & 25 & 4.84 & 10 & 23 & 5.08 & 24 \\
\hline Puerto Rico & 26 & 3.98 & 27 & 4.74 & 128 & 32 & 4.64 & 128 \\
\hline Estonia & 27 & 3.97 & 26 & 4.82 & 46 & 29 & 4.71 & 41 \\
\hline Portugal & 28 & 3.83 & 31 & 4.61 & 34 & 36 & 4.54 & 39 \\
\hline Saudi Arabia & 29 & 3.75 & 28 & 4.68 & 5 & 24 & 5.06 & 27 \\
\hline Malta & 30 & 3.75 & 29 & 4.67 & 47 & 47 & 4.45 & 32 \\
\hline Bahrain & 31 & 3.72 & 30 & 4.66 & 27 & 44 & 4.48 & 31 \\
\hline Israel & 32 & 3.64 & 33 & 4.59 & 36 & 27 & 4.95 & 23 \\
\hline Chile & 33 & 3.63 & 32 & 4.60 & 53 & 33 & 4.60 & 47 \\
\hline Oman & 34 & 3.61 & 34 & 4.57 & 26 & 46 & 4.46 & 42 \\
\hline Barbados & 35 & 3.61 & 35 & 4.56 & 83 & 55 & 4.36 & 36 \\
\hline Cyprus & 36 & 3.60 & 37 & 4.47 & 28 & 58 & 4.31 & 35 \\
\hline Mauritius & 37 & 3.48 & 36 & 4.50 & 63 & 39 & 4.52 & 53 \\
\hline
\end{tabular}


Table 6 cont.

\begin{tabular}{|l|l|l|l|l|l|l|l|l|}
\hline Spain & 38 & 3.46 & 43 & 4.37 & 22 & 35 & 4.55 & 29 \\
\hline Korea, Rep. & 39 & 3.45 & 39 & 4.42 & 33 & 26 & 4.96 & 25 \\
\hline Lithuania & 40 & 3.40 & 42 & 4.38 & 32 & 41 & 4.51 & 40 \\
\hline South Africa & 41 & 3.40 & 38 & 4.45 & 68 & 56 & 4.35 & 69 \\
\hline Latvia & 42 & 3.38 & 41 & 4.41 & 44 & 42 & 4.50 & 46 \\
\hline Jordan & 43 & 3.38 & 40 & 4.41 & 52 & 64 & 4.25 & 89 \\
\hline Slovenia & 44 & 3.33 & 56 & 4.14 & 42 & 70 & 4.22 & 33 \\
\hline Costa Rica & 45 & 3.33 & 44 & 4.37 & 78 & 51 & 4.42 & 62 \\
\hline Czech Republic & 46 & 3.28 & 46 & 4.34 & 40 & 37 & 4.53 & 34 \\
\hline Rwanda & 47 & 3.21 & 50 & 4.26 & 122 & 62 & 4.27 & 120 \\
\hline China & 48 & 3.20 & 45 & 4.36 & 88 & 28 & 4.89 & 75 \\
\hline Uruguay & 49 & 3.19 & 49 & 4.26 & 62 & 80 & 4.04 & 52 \\
\hline Panama & 50 & 3.18 & 47 & 4.32 & 59 & 48 & 4.43 & 54 \\
\hline Sri Lanka & 51 & 3.17 & 48 & 4.27 & 73 & 73 & 4.19 & 85 \\
\hline Indonesia & 52 & 3.11 & 51 & 4.25 & 87 & 34 & 4.57 & 93 \\
\hline Italy & 53 & 3.10 & 63 & 4.03 & 13 & 49 & 4.42 & 28 \\
\hline Turkey & 54 & 3.09 & 52 & 4.25 & 38 & 45 & 4.46 & 56 \\
\hline Poland & 55 & 3.09 & 53 & 4.21 & 41 & 43 & 4.48 & 43 \\
\hline
\end{tabular}

Source: Own elaboration using data from (Sala-i-Martín \& Schwab, 2014; PWT9.0).

which is the unweighted average of selected sub-pillars. For the sake of brevity only rankings of the first 52 countries are presented in the table. Examining Table 6 shows the differences between rankings of countries according to distinct criteria. For some countries there are remarkable differences between rankings with respect to $\mathrm{NC}$ as measured by $3 \mathrm{Dw}$ and productivity as measured by $\mathrm{GDP}^{\circ}$ per worker (GDP /emp in Table 6). For instance Finland, New Zealand, Hong Kong and Japan occupy leading positions in the 3Dw competitiveness ranking whereas their positions in the productivity ranking are much lower. Puerto Rico, just following France in the 3Dw ranking is near the bottom of the productivity ranking. On the other hand some highly productive countries like the USA or Ireland do not belong to the group of highly competitive countries.

The disparities between the rankings in question may have two sources, not necessarily disjointed. First, the production factors are the main driver of national productivity whereas NC plays an supporting role. In economies with very little international trade productivity is determined almost entirely by domestic factors (Krugman, 1994). The role of NC seems to be more important in countries with extensive international trade. Second, information about NC provided by sub-pillars is of varied quality and reliability since $70 \%$ of sub-pillars, used in the calculation of GCI and other indices are based on subjective opinions from surveys. 
There are also significant differences between rankings according to GCI and $\mathrm{GCI}_{\mathrm{EPS}}$. As mentioned in Section 3 GCI suffers from the presence of output-type sub-indices. This methodological drawback can be easily removed by eliminating these indices. $\mathrm{GCI}_{\mathrm{EPS}}$ is the index which is free from this drawback. If the changes in countries' positions when passing from the GCI ranking to the $\mathrm{GCI}_{\mathrm{ESP}}$ ranking are compared it can be seen that rich countries are losers whereas poorer countries are winners. It is clear that GCI is biased in favour of rich countries.

In order to appraise the indices of $\mathrm{NC}$, as the predictors of national productivity the panel-type models with $\mathrm{GDP}^{\circ}$ per worker as the dependent variable and 2Dw, GCI $\mathrm{ESP}_{\mathrm{EP}}$ and GCI as independent variables are estimated. The logarithmic version of $\mathrm{GDP}^{\circ}$ per worker is also used as the dependent variable. The fixed-effect version of the estimated models is applied (see Baltagi, 2005, for technical details). The results are presented in Table 7.

Table 7. Productivity as a function of national competitiveness 2010-2014

\begin{tabular}{|c|c|c|c|c|c|c|}
\hline & (1) & (2) & (3) & (4) & (5) & (6) \\
\hline & $\mathrm{GDP}^{\circ} / \mathrm{emp}$ & $\mathrm{GDP}^{\circ} / \mathrm{emp}$ & $\mathrm{GDP}^{\circ} / \mathrm{emp}$ & $\begin{array}{c}\log \mathrm{GDP}^{\circ} / \\
\text { emp }\end{array}$ & $\begin{array}{c}\log \operatorname{GDP}^{\circ} / \\
\text { emp }\end{array}$ & $\begin{array}{c}\log \operatorname{GDP}^{\circ} / \\
\text { emp }\end{array}$ \\
\hline \multirow[t]{2}{*}{$3 \mathrm{Dw}$} & $4063.2768^{* *}$ & & & $0.0991^{* *}$ & & \\
\hline & $(1197.5914)$ & & & $(0.0240)$ & & \\
\hline \multirow[t]{2}{*}{$\mathrm{GCI}_{\mathrm{ESP}}$} & & $5122.8153^{* *}$ & & & $0.1455^{* *}$ & \\
\hline & & $(1727.2783)$ & & & $(0.0345)$ & \\
\hline \multirow[t]{2}{*}{ GCI } & & & $11026.6607^{* *}$ & & & $0.2862^{* *}$ \\
\hline & & & (1829.9250) & & & $(0.03596)$ \\
\hline \multirow[t]{2}{*}{ _cons } & $32725.2940^{* *}$ & $23719.9239^{* *}$ & -2087.6399 & $9.9770^{* *}$ & $9.6725^{* *}$ & $9.0543^{* *}$ \\
\hline & (3591.7313) & $(7143.2729)$ & (7799.3507) & $(0.0719)$ & $(0.1426)$ & $(0.15327)$ \\
\hline $\mathrm{N}$ & 635 & 635 & 635 & 635 & 635 & 635 \\
\hline N_g & 127 & 127 & 127 & 127 & 127 & 127 \\
\hline $\mathrm{R}_{-}^{2} \mathrm{~W}$ & 0.02220 & 0.01705 & 0.0668 & 0.0326 & 0.0339 & 0.1111 \\
\hline $\mathrm{R}^{2} \_\mathrm{b}$ & 0.62590 & 0.5861 & 0.6141 & 0.5906 & 0.5531 & 0.6191 \\
\hline $\mathrm{R}_{-}^{2} \mathrm{O}$ & 0.61446 & 0.5740 & 0.6041 & 0.5821 & 0.5441 & 0.6113 \\
\hline
\end{tabular}

Note: Standard errors in parentheses ${ }^{+} p<0.10,{ }^{*} p<0.05,{ }^{* *} p<0.01$ 
In Table 7 the goodness of fit is presented by three coefficients of determination $R^{2}$. $R^{2}{ }_{-} w$ assesses the fit within countries, $R^{2} \_b$ assesses the fit between countries and $\mathrm{R}^{2}$ _o is the measure of overall fit. Examining Table 7 shows that two versions of the dependent variable (models 1-3 and 4-5) have comparable overall goodness of fit $\left(\mathrm{R}_{-}^{2} \mathrm{O}\right)$. Thus a non-logarithmic version of the models as the basis for comparisons may be selected.

If the $\mathrm{R}^{2} \mathrm{o}$ in models 2 and 3, or in models 5 and 6 is compared it can be seen that the inclusion of the output-type sub-indices and the state-of-development weights in calculating GCI improves goodness of fit. However such an improvement of fit is attained artificially by the use of a methodologically incorrect mixture of input-type and output-type sub-pillars.

If $\mathrm{R}^{2}$ _o in models 1 and 2 or in models 4 and 5 is compared it can be seen that $3 \mathrm{Dw}$ as a measure of $\mathrm{NC}$ performs better than $\mathrm{GCI}_{\mathrm{ESP}}$. This advantage of $3 \mathrm{Dw}$ over $\mathrm{GCI}_{\mathrm{ESP}}$ does not depend on the version of models, i.e. logarithmic or not. This means that $3 \mathrm{Dw}$ based on three orthogonal dimensions is a better predictor of productivity than $\mathrm{GCI}_{\mathrm{ESP}}$ the simple average of the selected sub-indices.

\section{Conclusions}

The search for the minimum number of uncorrelated dimensions of NC was motivated by the need for a precise measure of EP which affects national productivity. The economic model A-K accounts for EP as a catalyst. In this way NC can be anchored within the framework of the economic theory of production.

Since NC affects productivity from the input-side the output-side sub-pillars are neglected when searching for the hidden dimensions of NC. Three orthogonal (uncorrelated) principal components, $\mathrm{PC}_{1}, \mathrm{PC}_{2}$, and $\mathrm{PC}_{3}$, have been determined using PCA. A point in the three-dimension space describes the actual competitive position of a country. The distance from this point to the origin is a "natural" measure of the actual advancement of $a$ country in providing an attractive environment for firms. In general such a distance could be calculated when more than three dimensions of NC were determined.

The WEF's methodology also provides the three dimensions of NC, namely the super-pillars. GCI, as the weighted mean of the super-pillars, is an ultimate measure of NC. However such measurement suffers from serious drawbacks which make GCI a dubious measure of NC.

It has to be stressed that the critical remarks about the WEF methodology is a by-product of a careful inspection of sub-pillars. The drawback in question appeared quite unexpectedly. It can be easily overlooked when an analyst is interested solely in pillars, super-pillars or GCI. The drawback can be removed by a proper selection of sub-pillars.

It seems that in the new 2018 GCR (Schwab, 2018) WEF has made an important step towards improving its methodology in abandoning the use of the 
stage-of development weights. However the GDP-contaminated sub-pillars have been still applied in the calculation of GCI and other indices. One may expect that the next GCRs will be free from this shortfall.

\section{Annex 1 \\ The selected components of the social, institutional and infrastructural competitiveness}

\section{Social competitiveness}

Health: 4.01 Business impact of malaria, 4.02 Malaria incidence, 4.03 Business impact of tuberculosis, 4.04 Tuberculosis incidence, 4.05 Business impact of HIV/AIDS, 4.06 HIV prevalence, 4.07 Infant mortality, 4.08 Life expectancy. Education: 4.09 Quality of primary education, 4.10 Primary education, enrolment rate, 5.01 Secondary education enrolment rate, 5.02 Tertiary education enrolment rate, 5.03 Quality of the educational system, 5.04 Quality of math and science education, 5.05 Quality of management schools, 5.06 Internet access in schools.

Science: 12.02 Quality of scientific research institutions, 12.04 Universityindustry collaboration in R\&D, 12.06 Availability of scientists and engineers, 12.07 PCT patent applications.

\section{Institutional competitiveness}

State institutions: 1.01 Property rights, 1.02 Intellectual property protection, 1.03 Diversion of public funds, 1.04 Public trust of politicians, 1.05 Irregular payments and bribes, 1.06 Judicial independence, 1.07 Favouritisms in decisions of government officials, 1.08 Wastefulness of government spending, 1.09 Burden of government regulation, 1.10 Efficiency of legal framework in settling disputes, 1.11 Efficiency of legal framework in challenging regulations, 1.12 Transparency of government policymaking, 1.13 Business costs of terrorism, 1.14 Business costs of crime and violence, 1.15 Organized crime, 1.16 Reliability of police services, 1.20 Protection of minority shareholders' interests, 1.21 Strength of investor protection, 12.05 Government procurement of advanced technology products.

Institutional regulation of goods and services markets and labour market: 6.03 Effectiveness of anti-monopoly policy, 6.04 Effect of taxation on incentives to invest, 6.05 Total tax rate, 6.06 Number of procedures required to start a business, 6.07 Time required to start a business, 6.08 Agricultural policy costs, 6.09 Prevalence of trade barriers, 6.10 Trade tariffs, 6.11 Prevalence of foreign ownership, 6.12 Business impact of rules on FDI, 6.13 Burden of customs procedures, 7.02 Flexibility of wage determination, 7.03 Hiring and fir- 
ing practices, 7.04 Redundancy costs, 7.05 Effect of taxation on incentives to work, 7.08 Country capacity to retain talent, 7.09 Country capacity to attract talent, 7.10 Female participation in labour force.

Financial system of the state: 8.01 Availability of financial services, 8.02 Affordability of financial services, 8.03 Financing through local equity market, 8.04 Ease of access to loans, 8.05 Venture capital availability, 8.06 Soundness of banks, 8.07 Regulation of securities exchanges, 8.08 Legal rights index.

\section{Infrastructural competitiveness}

Transport infrastructure: 2.01 Quality of overall infrastructure, 2.02 Quality of roads, 2.03 Quality of railroad infrastructure, 2.04 Quality of port infrastructure, 2.05 Quality of air transport infrastructure, 2.06 Available seat kilometres. Energy and telecommunications infrastructure: 2.07 Quality of electricity supply, 2.08 Mobile-cellular telephone subscriptions, 2.09 Fixed-telephone lines, 9.04 Internet users, 9.05. Fixed-broadband Internet subscriptions, 9.06 Internet bandwidth, 9.07 Mobile-broadband subscriptions.

\section{Annex 2 \\ The selected components of the Micro-EP competitiveness}

1.17 Ethical behaviour of firms, 1.18 Strength of auditing and reporting standards, 1.19 Efficacy of corporate boards, 5.07 Local availability of specialized research and training services, 5.08 Extent of staff training, 6.01 Intensity of local competition, 6.02 Extent of market dominance, 6.15 Degree of customer orientation, 6.16 Buyer sophistication, 7.01 Cooperation in labour-employer relations, 7.06 Pay and productivity, 7.07 Reliance on professional management, 9.01. Availability of latest technologies, 9.02 Firm-level technology absorption, 9.03 FDI and technology transfer, 11.01 Local supplier quantity, 11.02 Local supplier quality, 11.03 State of cluster development, 11.04 Nature of competitive advantage, 11.05 Value chain breadth, 11.06 Control of international distribution, 11.07 Production process sophistication, 11.08 Extent of marketing, 11.09 Willingness to delegate authority, 12.01 Capacity for innovation, 12.03 Company spending on R\&D.

\section{References}

Adamkiewicz, H. G., \& Kot, S.M. (2015). International competitiveness as the catalyst of productivity. International Review of Business Research Papers, 6, 120-131.

Aiginger, K. (2006). Competitiveness: From a dangerous obsession to a welfare creating ability with positive externalities. Journal of Industry, Competition and Trade, 6, 161-177.

Baltagi, B. H. (2005). Econometric analysis of panel data. Chichester: Wiley \& Sons. 
Bankova, Y. (2015). Critical success factors of national competitiveness. International Scientific Conference: Challenges in business and economics: Growth, competitiveness and innovations. Niš, October 16, 2015. Retrieved from http:// http://isc2015. ekonomskifakultet.rs/ISCpdfs/ISC2015-10.pdf.

Bhawsar, P., \& Chattopadhyay, U. (2015). Competitiveness: Review, reflections and directions. Global Business Review, 16, 665-679.

Boltho, A. (1995). The assessment: International competitiveness. Oxford Review of Economic Policy, 12, 1-16.

Caselli, F. (2005). Accounting for cross-country income differences. In P. Aghion, S. Durlauf (Eds.), Handbook of economic growth (pp. 679-741). Amsterdam: Elsevier.

Cho, D.-S., Moon, H.-C., \& Kim M.-Y. (2009). Does one size fit all? A dual double diamond approach to country-specific advantages. Asian Business and Management, 8(1), 83-102.

Cho, D.-S., \& Moon, H.-C. (2000). National competitiveness: A nine factor approach and its empirical application. Journal of International Business and Economy, 1(1), 17-38.

Cox, M. A. A. (2001). Multidimensional scaling. London: Chapman \& Hall.

De Grauwe, P. (2010). Introduction. In P. De Grauwe (Ed.), Dimensions of competitiveness (pp. ix-xvi). CESifo Seminar Series. Cambridge: MIT Press.

Delgado, M., Ketels, C., Porter, M. E., \& Stern, S. (2012). The determinants of national competitiveness. (NBER Working Paper No. 18249).

Delgado, M., Porter, M. E., \& Stern S. (2010). Clusters and entrepreneurship. Journal of Economic Geography, 10, 495-518.

Feenstra, R. C., Inklaar, R., \& Timmer, M. P. (2015). The next generation of the Penn World Table. American Economic Review, 105, 3150-3182.

Garelli, S. (2012). The fundamentals and history of competitiveness. In IMD World Competitiveness Yearbook, 488-503.

Glaeser, E., La Porta, R., Lopez-de-Silanes, F., \& Shleifer, A. (2004). Do institutions cause growth?. Journal of Economic Growth, 9, 271-303.

Grilo, I., \& Koopman, G. J. (2006). Productivity and microeconomic reforms: Strengthening EU competitiveness. Journal of Industry, Competition and Trade, 6, 67-84.

Huggins, R., \& Davies, W. (2006). European Competitiveness Index 2006-07. University of Wales of Wales Institute, Cardiff-UWIC: Robert Huggins Associates Ltd.

Jolliffe, I. T. (2002). Principal component analysis. New York: Springer.

Kaiser, H. F. (1960). The application of electronic computers to factor analysis. Educational and Psychological Measurement, 20, 141-151.

Kaiser, H. F. (1974). An index of factor simplicity. Psychometrika, 39, 31-36.

Kohler, W. (2006). The 'Lisbon Goal' of the EU: rhetoric or substance?. Journal of Industry, Competition and Trade, 6, 85-113.

Krugman, P. D. (1994). Competitiveness: A dangerous obsession. Foreign Affairs, 73, 28-44.

Lall, S. (2001). Competitiveness indices and developing countries: An economic evaluation of the Global Competitiveness Report. World Development, 29, 1501-1525.

Liu, Ch. (2017). International competitiveness and the fourth industrial revolution. Entrepreneurial Business and Economics Review, 5(4), 111-133.

Mankiw, M. G., Romer, D., \& Weil D. N. (1992). A contribution to the empirics of economic growth. Quarterly Journal of Economics, 107, 407-437. 
Martin, R. L. (2004). A study on the factors of regional competitiveness. A draft final report for the European Commission, Directorate-General Regional Policy (after: Bankova, 2015).

Moon, H. C., Rugman, A., \& Verbeke, A. (1998). A generalized double diamond approach to the competitiveness of Korea and Singapore. International Business Review, 7, 135-150.

Nunnally, J. C. (1978). Psychometric theory. New York: McGraw-Hill.

Porter, M. E. (1990a). The competitive advantage of nations. New York: The Free Press.

Porter, M. E. (1990b, March-April). The competitive advantage of nations. Harvard Business Review, 68, 73-91.

Rugman, A. M., \& D'Cruz, J. R. (1993). The 'double diamond' model of international competitiveness: The Canadian experience. Management International Review, 33, 17-39.

Sala-i-Martín, X., \& Schwab, K. (2010). The Global Competitiveness Report 2010-2011. Geneva: World Economic Forum.

Sala-i-Martín, X., \& Schwab, K. (2011). The Global Competitiveness Report 2011-2012. Geneva: World Economic Forum.

Sala-i-Martín, X., \& Schwab, K. (2012). The Global Competitiveness Report 2012-2013. Geneva: World Economic Forum.

Sala-i-Martín, X., \& Schwab, K. (2013). The Global Competitiveness Report 2013-2014. Geneva: World Economic Forum.

Sala-i-Martín, X., \& Schwab, K. (2014). The Global Competitiveness Report 2014-2015. Geneva: World Economic Forum.

Sala-i-Martín, X., \& Schwab, K. (2015). The Global Competitiveness Report 2015-2016. Geneva: World Economic Forum.

Sala-i-Martín, X., \& Schwab, K. (2016). The Global Competitiveness Report 2016-2017. Geneva: World Economic Forum.

Sala-i-Martín, X., \& Schwab, K. (2017). The Global Competitiveness Report 2017-2018. Geneva: World Economic Forum.

Schwab, K. (2018). The Global Competitiveness Report 2018. Geneva: World Economic Forum.

Siggel, E. (2006). International competitiveness and comparative advantage: A survey and a proposal for measurement. Journal of Industry, Competition and Trade, 6, 137-159.

Zinnes, C., Eliat, Y., \& Sachs, J. (2001). Benchmarking competitiveness in transition economies. Economics of Transition, 9, 315-353. 